University of Nebraska - Lincoln

DigitalCommons@University of Nebraska - Lincoln

Sociology Department, Faculty Publications

Sociology, Department of

2021

\title{
LGBT Employment Nondiscrimination: Debating Sexuality and Citizenship
}

Kelsy Burke

Emily Kazyak

Alice MillerMacPhee

Follow this and additional works at: https://digitalcommons.unl.edu/sociologyfacpub

Part of the Family, Life Course, and Society Commons, and the Social Psychology and Interaction Commons

This Article is brought to you for free and open access by the Sociology, Department of at DigitalCommons@University of Nebraska - Lincoln. It has been accepted for inclusion in Sociology Department, Faculty Publications by an authorized administrator of DigitalCommons@University of Nebraska - Lincoln. 


\title{
LGBT Employment Nondiscrimination: Debating Sexuality and Citizenship
}

\author{
Kelsy Burke, Emily Kazyak, \& Alice MillerMacPhee \\ University of Nebraska-Lincoln, Lincoln, NE, USA \\ Correspondence - Kelsy Burke, kburke@unl.edu
}

\begin{abstract}
Introduction - Nebraska is 1 of 26 states that did not protect LGBT people from employment discrimination prior to Bostock vs. Clayton County. This article examines debates in Nebraska about LGBT employment nondiscrimination as a window into how citizenship is defined in relation to sexuality and gender identity.

Methods - We performed qualitative analyses on (1) the 2018 Nebraska Annual Social Indicators Survey of 902 respondents who shared their opinions on employment nondiscrimination legislation for LGBT individuals in close- and openended questions and (2) transcripts of the 2017 Nebraska state legislature debate of a bill that would have added sexual orientation and gender identity to the classes protected from employment discrimination.

Results - We find overlap in the primary frames employed by advocates and opponents. Both frame sexuality and gender as irrelevant to employment, and both rely on fairness and equality as rationales. Both sides also use a morality frame; however, those opposing argue that passage may result in discrimination based on religion.

Conclusions - While civil rights are often assumed to be conferred on all people designated as citizens in a society, this paper reveals that LGBT people's inclusion in the state remains contested. Both sides articulate that the state is not neutral but is expected to be an enforcer of values through policies implicating gender and sexuality.
\end{abstract}

Published in Sexuality Research and Social Policy (2021), doi:10.1007/s13178-021-00561-2 Copyright (C) 2021 Kelsy Burke, Emily Kazyak, \& Alice MillerMacPhee. Published by Springer Science+Business Media, LLC. Used by permission. Accepted 8 March 2021; published 19 March 2021 
Policy Implications - Because LGBT nondiscrimination policies tap into broader debates over freedom, morality, and citizenship, these will likely continue to be contested in the years following the Supreme Court's ruling that protects against employment discrimination.

Keywords: Discrimination, Employment, Framing, LGBT, Nebraska, Public opinion, Religious right

In 2020, the Supreme Court ruled in Bostock v. Clayton County that discrimination against LGBT people was considered sex discrimination and thus prohibited by Title VII of the Civil Rights Act. Before this ruling, state laws varied on whether sexual orientation and gender identity were included as protected classes in nondiscrimination law (Baumle et al., 2019). At the time of the Bostock ruling, 26 states did not protect LGBT people in their state nondiscrimination laws. This article focuses on one such state, Nebraska, where a sexual orientation and gender identity nondiscrimination law does not exist, despite being introduced and debated in every legislation session since 1999 .

We use the case of public policy debates in Nebraska about LGBT employment nondiscrimination as a window into the broader question: how do sexuality and gender identity matter to notions of citizenship in an era of increasing acceptance and rights protecting LGBT Americans? We draw from an expansive definition of citizenship conceptualized by sociolegal scholars to mean a sense of belonging to a nation state that includes a set of shared rights (Minow, 1987; Richardson, 2018; Ygnvesson, 1993). As this scholarship underscores, these rights are not static nor settled in the law. Rather, they are open to debate and continually negotiated within what Ferree et al. (2002) call "arenas of discourse," where lawmakers influence and are influenced by a wide range of social actors, including elected officials, activists, and laypeople.

This article draws from two data sources to compare how multiple actors frame LGBT rights. First, we analyzed data from a 2018 survey that is representative of Nebraska residents, whom we call "ordinary citizens." These survey data included two close-ended questions that asked about opinions on employment nondiscrimination legislation for gays and lesbians and transgender individuals as well as two open-ended questions that asked respondents to explain why they favored or opposed employment nondiscrimination legislation. Second, 
we analyzed data from the 2017 session of the Nebraska state legislature, which included a committee hearing and legislative floor debate of a bill that would have added sexual orientation and gender identity to the classes protected from employment discrimination. These data included both remarks and debate from elected officials (state senators) as well as testimony from individuals, whom we call "motivated citizens," who spoke in support of or opposition to the bill.

On both sides of LGBT employment nondiscrimination debates, we find that all social actors-ordinary citizens, motivated citizens, and elected officials-used ideal notions of citizenship to shape their positions. These include broad ideas about the role of the state-that it is moral, fair, and diverse-and specific implications for sexual and gender minorities. These sides differed when claims moved beyond abstract ideals to the practical realities of citizenship. Here, each side came to different conclusions on facts and claims of how employment discrimination occurs. Our findings note patterns as well as nuance across different types of social actors and offer implications for public policy and scholarship on sexuality and citizenship.

\section{Sexual Citizenship and Framing Debates Over LGBT Rights}

As Richardson (2018) outlines, the concept of citizenship has been used to refer to a set of rights granted to members of a nation state as well as to a set of practices that demark boundaries and produce imagined sentiments of belonging and inclusion/exclusion, either to a nation state or even a global human community (e.g., Pakulski, 1997; Turner, 1993). Scholars have demonstrated how sexuality matters to citizenship, insofar as the state regulates sexual matters (Puri, 2016), access to rights are granted or denied on the basis of sexuality (Bernstein \& Reimann, 2001; Richardson, 2018), and heterosexuality has undergirded state policies and ideals of citizenship (Barclay et al., 2009; Canaday, 2009). Synthesizing this literature, Carrillo (2017) defines sexual citizenship as "a diverse assortment of political, social, and cultural claims and struggles that link notions of sexual rights and duties to membership in nations or other political communities" (p. 16o). In other words, sexual citizenship can be understood as the "right to belong" alongside recognition of sexual rights. Indeed, 
research suggests that LGB people living in states with nondiscrimination policies that are inclusive of sexual orientation perceive their environment more positively than LGB people living in states without such legal protection (Riggle et al., 2010).

Our findings expand this literature now that we live in a post-gay marriage society, where heterosexuality is no longer attached to a key marker of citizenship in the case of marriage and where being gay is visible and normalized (Ghaziani \& Baldassarri, 2011; Walters, 2016). Still, a rich body of work theorizes that efforts to legalize same-sex marriage exemplified the relationship between heteronormativity and the state as marriage rights for same-sex couples reinforce hegemonic heterosexual understandings of marriage and family life (Bernstein \& Reimann, 2001; Canaday, 2009; Richardson, 2018; Vitulli, 2010). Moreover, scholars note that LGBT people face incomplete recognition of citizenship in other arenas beyond marriage (Mucciaroni, 2009). Other research has found that even in states with a majority supporting transgender rights, legislators often will not take action in confirming bills that include protections for transgender people (Flores et al., 2015). These examples illustrate how federal and state protections for LGBT people remain an incomplete and contentious issue in American society (see also Baumle et al., 2019; Worthen, 2019).

In addition to theories about sexuality and citizenship, we also draw on social movement scholarship to analyze the frames employed by different social actors. Frames refer to the construction of messaging and linguistic devices used in communicating the values and beliefs of the speaker and often suggest an action to be taken to advance those beliefs. Frames contain underlying assumptions about the issue under debate and can impact the success of social movements and policy adoption insofar as they have the potential to persuade others (Benford \& Snow, 2000; Snow et al., 2014; Van Dyke \& Taylor, 2019). Framing efficacy can substantively advance social movement outcomes (Cress \& Snow, 2000), but framing processes are often complex and do not reflect a simple and continuous dichotomy between advocates and opponents. Additionally, framing employed by non-elite actors (i.e., the general public) to advance rights does not necessarily mirror that used by elites (i.e., elected representatives) (Hull, 2001).

Still, research has shown that elected representatives respond to the concerns of constituents underscoring that the frames citizens use 
in their testimonies during legislative debates, for instance, can have a direct impact on legislative decisions (see McCammon et al., 2007, 2008; Vasi et al., 2015). Gruszczynski and Michaels (2014) found that state and federal-level elected representatives incorporated concerns raised by local citizens into their strategic framing arguing in favor of the construction of a local waterway. Variations in framing around immigration and access to social and educational services have also influenced the types of policies adopted at the state level (Brown, 2013; Reich \& Mendoza, 2008).

Activism and policy advocacy around LGBT rights specifically illustrate the efficacy of framing and how framing may differ by actors and change over time in response to opposing movements (Valocchi, 1999). In analyzing same-sex marriage debates in Connecticut, Olsen (2014) found that self-identified gays and lesbians were able to use a combination of personal narrative and framing to effectively engage legislators. However, opposing sides can wield framing as a dynamic process. Stone (2019) found that religious conservatives adjusted frames to oppose LGBT rights between 1973 and 2013 by first rhetorically using a "stranger danger" frame to construct gay men and transgender women as dangerous others, but gradually shifting to more generic pro-family frames. Additionally, frames originally developed by queer activists have the potential to be co-opted by those in opposition thus altering the meaning and interpretation of those frames (Burke \& Bernstein, 2014).

Research on anti-LGBT movements in the USA has found that individuals oppose extending civil rights to LGBT people by referencing their religious beliefs (i.e., conservative Christian values) (see Fetner, 2008; Herman, 1997; Stone, 2019). According to legal scholar Hamilton (2015, p. 140), religious persons have "a significantly higher likelihood of success" when claiming religious grounds for actions that may violate the law, like discrimination in the workplace. The conflict over religious freedom and civil rights in the workplace is not unique to LGBT politics. The federal Civil Rights Act requires that employers accommodate religious exemption requests so long as these requests do not cause "undue hardship" on employers. Definitions of "religious freedom," however, remain murky because "undue hardship" is a subjective measure. Historically, religious groups attempted and failed to be exempt from laws that prohibit racial discrimination (Minow, 1987; 
Turley, 2008). Bob Jones University, for example, lost its tax-exempt status when it continued to prohibit interracial marriages after Loving $v$. Virginia rejected this prohibition in 1967. Nondiscrimination laws signal that the failure to protect gays and lesbians is morally wrong. Religious exemptions to these laws, however, signal that the exclusion of gays and lesbians is morally permissible.

Religious conservatives opposed to the expansion of LGBTQ rights have argued that these are "special rights" sexual and gender minorities do not deserve because such rights indicate unfairness (GoldbergHiller \& Milner, 2003; Lewis, 2017; Stein, 2001; Stone, 2016). Fairness and equality are widely shared beliefs across the political and religious spectrum (Bonikowski \& DiMaggio, 2016; Mucciaroni, 2009). Political ideology matters insofar as liberal and conservative ideologies are associated with fundamentally different moral frames with regard to citizens' rights and responsibilities. Feinberg and Willer (2015) used an experimental design employing vignettes and found differences in the moral rhetoric used by liberals and conservatives to frame political issues such as same-sex marriage, universal healthcare, and military spending. Those identifying as liberal relied more often on appeals to fairness whereas conservatives appealed to moral purity and the authority of the state, and in both cases, individuals were more likely to be persuaded by moral framing congruent with their own ideological orientation. However, as Lewis (2017) documents, religious conservatives in the USA are increasingly using liberal arguments related to civil rights in public discourse.

Framing, as a social psychological process, can also function as a "window" into underlying ideologies thus illuminating broader systems of belief and understanding (Oliver \& Johnston, 2005). Berrey et al. (2017) argue that Americans tend to frame and interpret employment discrimination at the individual level, viewing it as something that occurs as a result of individuals holding prejudicial attitudes (as opposed, for instance, to viewing it as something that can occur as a result from systematic biases built into institutions and culture). Additionally, research suggests that analysis of framing within a legal context is especially important as challengers often use legal concepts (e.g., rights) in their framing simultaneously relying on and challenging existing law, and if successful, their frame is codified into law (Pedriana, 2006). Drawing on these bodies of literature, we analyzed the 
framing and discourses used in debates in Nebraska about LGBT employment nondiscrimination by three different social actors: ordinary citizens, motivated citizens, and elected officials.

\section{Methods}

\section{Nebraska as a Case Study}

Although not generalizable to the USA, Nebraska serves as an informative case study for analyzing how and when sexuality and gender matter to understandings of citizenship. First, although Nebraska is more politically conservative than the national average, the state is comparable with the rest of the nation when it comes to attitudes about LGBTQ rights (Kazyak et al., 2018; Stange \& Kazyak, 2016). Nebraska voters overwhelmingly supported a ban on same-sex marriage in a 2000 referendum (Adam, 2003; Rasmussen, 2006), and the GOP, which largely controls the state government despite the technically nonpartisan Unicameral legislature, continues to advocate for defining marriage as the union between one man and one woman. Yet in the decade that followed the ban on same-sex marriage, the flagship state university, some school districts, hospitals, business, and city and county governments extended benefits to same-sex couples (Dejka, 2013; Funk, 2013; Glissmann, 2013; Reed, 2012). Moreover, recent analyses indicate that the majority of Nebraskans support samesex marriage and other LGBTQ rights and that Nebraskans' opinions mirror national public opinion on these issues.

Additionally, Nebraska is fairly average when it comes to measures of religiosity. A Pew Research Center (2014) ranks it the 22nd most religious state, based on the percentage of residents who say religion is very important in their lives (54\%), that they attend worship services weekly (39\%), that they pray daily (52\%), and that they believe in God with certainty (69\%). It is neither highly religious like states in the South (Mississippi and Alabama are tied for the most religious), nor highly secular like states in the Northeast (New Hampshire and Massachusetts are tied for least religious). Moreover, religious affiliations in the state are comparable with the rest of the nation. Seventy-five percent of Nebraska residents identify as Christian compared 
with $71 \%$ of Americans overall. White evangelical Protestants make up about $25 \%$ of the population in Nebraska and the country.

Nebraska's employment nondiscrimination law does not include sexual orientation and gender identity among the list of protected classes, which aligns with 25 other states (Movement Advancement Project, 2020). However, debate has occurred in the state about this issue since 1999 when state senators first introduced a bill that would add sexual orientation to the state's employment nondiscrimination law. Bills have been introduced in each subsequent legislative session and were expanded to include gender identity in addition to sexual orientation in the 2015 session. Legislative sessions include both testimony from individuals and organizations provided before committees and debate among the state senators on the legislative floor. Thus, Nebraska is an informative case study insofar as the question of LGBT employment nondiscrimination is one that is salient in the state and one that has been debated by multiple social actors.

\section{Data}

Our data come from two sources. First, we analyzed data from a 2018 survey that is representative of Nebraska residents, the Nebraska Annual Social Indicators Survey (NASIS). Survey respondents, whom we refer to as "ordinary citizens," responded to two close-ended questions that asked about opinions on employment nondiscrimination legislation for gays and lesbians and transgender individuals as well as two open-ended questions that asked respondents to explain why they favor or opposed employment nondiscrimination legislation (see Table 1). Second, we analyzed data from the 2017 meeting of the Nebraska state legislature, which included introduction and debate of a bill that would have added sexual orientation and gender identity to the classes protected from employment discrimination. This data included testimony from civically engaged citizens who testified either in support or opposition of the proposed bill, whom we refer to as "motivated citizens," and remarks and debates from Nebraska state senators whom we refer to as "elected officials."

NASIS is an annual, cross-sectional, omnibus survey of Nebraska adults ages 19 and older, which is conducted by the Bureau of Sociological Research at the University of Nebraska-Lincoln (UNL). The 
Table 1 NASIS question wording

\begin{tabular}{|c|c|}
\hline Question & Response option \\
\hline Do you favor or oppose laws to protect gay men and lesbians from job discrimination? & Favor/oppose \\
\hline Do you favor or oppose laws to protect transgender individuals from job discrimination? & Favor/oppose \\
\hline Why do you favor or oppose laws to protect transgender individuals from job description? & Open-ended text box \\
\hline
\end{tabular}

2018 NASIS was a mail survey sent to randomly selected addressbased sample of 3600 Nebraska households that was provided by Survey Sampling International (SSI). Respondents were selected within sampled households using the next birthday technique. Data collection consisted of three mailings (initial survey packet with a $\$ 1$ cash incentive, postcard reminder, and a replacement survey packet) sent between July 24 and October 30, 2018. A total of 938 respondents completed NASIS 2018, for a response rate of $26.1 \%$ (The American Association for Public Opinion Research, 2016).

NASIS data has the advantage of not only quantitatively measuring people's views on employment nondiscrimination laws related to sexual orientation and gender identity but also including data on how people justify their view. The latter is the focus of our analysis for this paper. A total of 902 answered the closed-ended, favor/ oppose question related to gay men and lesbians, and 877 answered the close-ended favor/oppose question related to transgender individuals. A majority (691 for the question about gays and lesbians and 600 for the question about transgender individuals) elaborated on their opinion by writing a response to the open-ended question. Responses were typically brief (one to two sentences), but capture the frameworks that are available to people as they make sense of LGBT employment nondiscrimination laws (Blair-Loy, 2001; Snow et al., 2014).

The legislative data come from the 2017 session of the Nebraska Unicameral, including the judiciary committee hearings and a legislative floor debate regarding a proposed LGBT employment nondiscrimination bill. Data include the transcript from the 2017 judiciary committee hearing related to LB173, a proposed bill that would have prohibited workplace discrimination based on sexual orientation and gender identity in Nebraska, and the Unicameral floor debate in which state senators debated the passage of LB173. We obtained these 
transcripts through the Nebraska State Legislature webpage (https:// nebraskalegislature.gov). The judiciary committee transcript is a verbatim record of the LB173 hearing before the Judiciary Committee on February 22, 2017. The floor debate is a verbatim record of the Unicameral debate of LB173 on April 6, 2017.

For the floor debate, we treated public utterances as our unit of analysis to see how logics and positions change over the course of the debate since individual senators can speak multiple times. The floor debate begins with opening remarks delivered by the senator who has sponsored the bill. Each senator present in the chamber may then provide comments or ask questions associated with the proposed bill. They may speak up to three turns with each turn a maximum of $5 \mathrm{~min}$, and a senator may yield their time to another senator of their choosing. Finally, the bill's sponsor may offer concluding remarks of up to 5 min provided they have one of their three speaking turns remaining. The Speaker of the Unicameral determines the length of time permitted for the floor debate, and as this was the first round of debate for LB173, $3 \mathrm{~h}$ was allotted. We coded each statement made by a senator as a separate utterance. Twenty-five senators made a total of 39 utterances.

During the judiciary committee hearing, individuals were given 3 min to provide testimony followed by the option for senators to ask questions. All those testifying in support of a bill speak first, followed by those testifying against, and the hearing concludes with any making statements that are neutral. A total of 40 individuals testified in response to the introduction of LB173. Among those testifying in support included LGBT individuals and representatives from organizations such as the Lincoln and Omaha Chambers of Commerce, Nebraskans for Peace, and the Nebraska chapter of the National Association of Social Workers, and one representing a religious group, the Unitarian Church of Lincoln. Among those testifying in opposition included individuals and representatives from nonprofit organizations such as the Nebraska Family Alliance and the Thomas More Society, and two religious groups, the Nebraska Catholic Conference and the Word of Life Community Church. While the judiciary committee hearing includes comments and questions from senators, we coded only those statements provided by citizens. In these deliberations, our primary concern is understanding how motivated citizens framed their statements. 


\section{Analysis}

Comparing across these sources of data allow us to understand how different actors (ordinary citizens, elected officials, and motivated citizens) may use different rationales to explain their position. First, we analyzed the percentages of NASIS respondents who favored and opposed employment nondiscrimination for gays and lesbians and transgender individuals. We also recorded each motivated citizen and elected officials' stance on LB173. Our primary focus of analyses centered on qualitative data. Qualitative analysis allows us to move beyond the quantitative outcomes of "favor vs. oppose" to hear from survey respondents, legislators, and individuals who gave public testimony about how they contextualize their views on a complex issue implicated by employment nondiscrimination laws. We focused our analysis on uncovering the frames used by each side and by different social actors in explaining their position on LGBT employment nondiscrimination laws. We analyzed the degree to which there were overlaps in the frames and discourses used by those who oppose and favor LGBT employment nondiscrimination laws. We also noted whether there were overlaps among the three social actors (ordinary citizens, motivated citizens, and elected officials).

Qualitative coding of the open-ended survey responses and legislative transcripts was iterative. First, all three authors read all data, and each author generated an initial list of codes that emerged from the data (Crabtree \& Miller, 1992). Second, the authors cross-checked provisional codes and discussed common themes. These provisional codes - ones that were present to at least some extent across all data sets-became the basis for axial coding, which tested the relationships among emerging categories and confirmed whether or not these themes continued to emerge from the data (Corbin \& Strauss, 1990). To assist with coding open-ended survey data, two research assistants coded the remaining responses, while meeting with the authors to discuss coding decisions and maintain consistency. The authors coded all legislative transcripts. After coding each source of data separately, we then analyzed codes that appeared across data sources, looking at which codes were most used overall as well as by groups who favor and groups who oppose the law. 


\section{Results}

When it comes to employment nondiscrimination, Table 2 shows that $76.4 \%$ of ordinary citizens in Nebraska are in favor for gays and lesbians and $72.6 \%$ for transgender individuals. Survey results reflect similar patterns that appeared in the testimony by motivated citizens insofar as 25 individuals testified in support of LB173 (about 63\% of the overall testimony) with 15 testifying in opposition (about $37 \%$ of the overall testimony). With regard to elected officials, 32 of 39 statements were in support (about $82 \%$ ). This percentage is likely significantly higher than senators' actual viewpoints given that the proposed legislation failed to reach a floor vote (just has it had in prior session). Knowing that a vote was unlikely, senators likely did not feel the need to voice their opposition during the debate.

Across social actors, we identified three core themes across nine inductive codes. These broader themes-the moral state, the fair state, and the diverse state-organize our findings below. As described in Table 3 , there is significant overlap in codes within these themes across position about employment nondiscrimination (favor or oppose). Codes across both sides of the debate include (1) that morality informs their position (codes: God, Universal truth), (2) that sexuality should be irrelevant in the context of employment (codes: Irrelevant, Identity, and Personal), and (3) that fairness, freedom, and equality are core dimensions of American citizenship (codes: Discrimination, Equality, First Amendment, and Special treatment).

Table 2 Percentage favor and opposition for LGBT employment nondiscrimination law across data sets

\begin{tabular}{lll} 
& $\begin{array}{l}\text { Percentage } \\
\text { in favor }(N)\end{array}$ & $\begin{array}{l}\text { Percentage } \\
\text { in opposition (N) }\end{array}$ \\
\hline $\begin{array}{l}\text { NASIS respondents (ordinary citizens) re: gay and lesbian } \\
\text { employment nondiscrimination }\end{array}$ & $76.4 \%(689)$ & $23.6 \%(213)$ \\
$\begin{array}{l}\text { NASIS respondents (ordinary citizens) re: transgender } \\
\text { employment nondiscrimination }\end{array}$ & $72.6 \%(637)$ & $27.4 \%(241)$ \\
$\begin{array}{l}\text { Judiciary Committee testimony (motivated citizens) } \\
\text { Unicameral floor debate (elected officials) }\end{array}$ & $\begin{array}{l}62.5 \%(25) \\
82.1 \%(32)\end{array}$ & $\begin{array}{l}37.5 \%(15) \\
17.9 \%(7)\end{array}$ \\
\hline
\end{tabular}




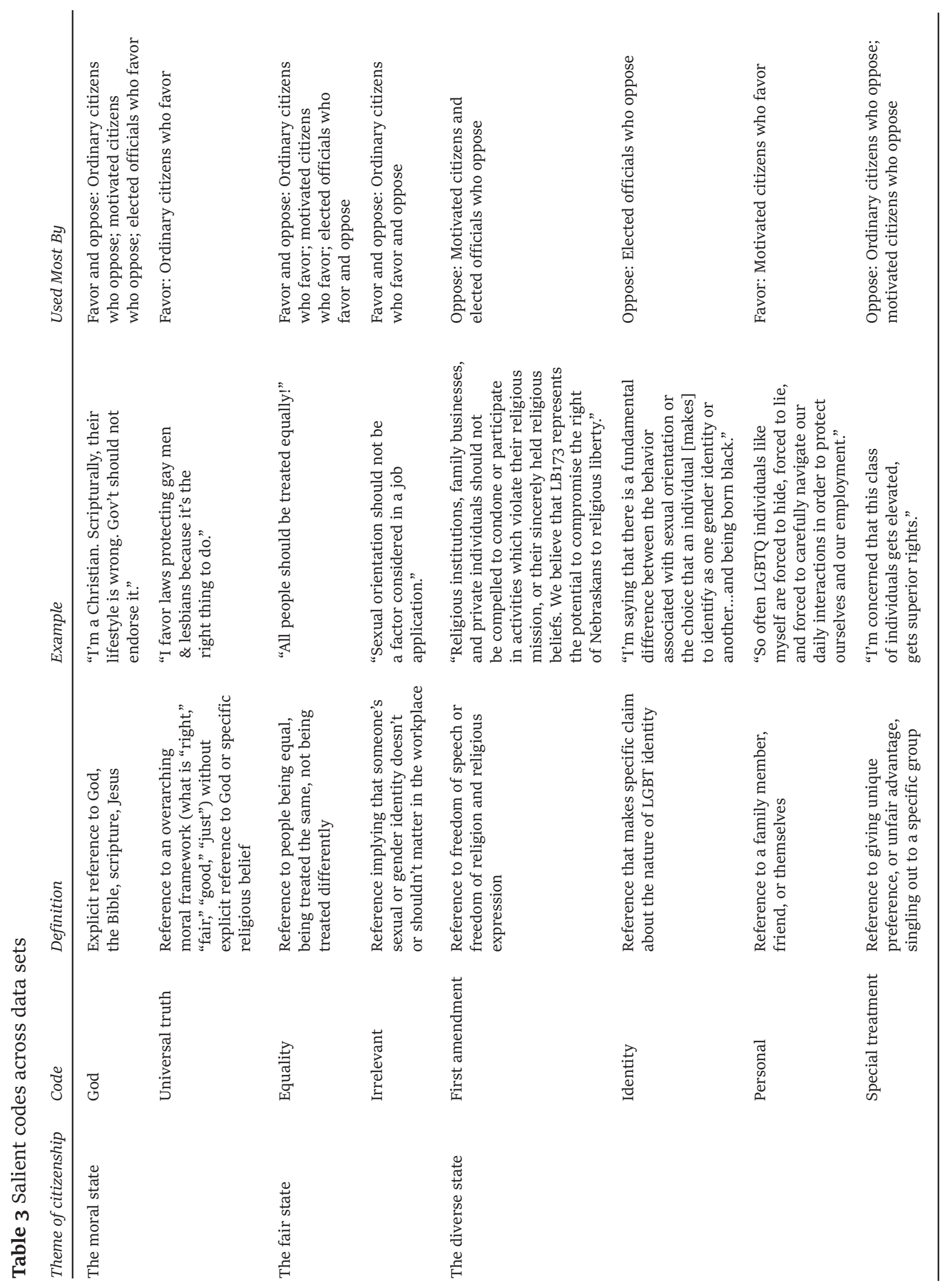




\section{The Moral State: Upholding the Fundamental Rights of Citizenship}

Individuals on both sides of the employment nondiscrimination debate emphasize that rights associated with citizenship are determined by a higher power-sometimes explicitly a Christian God and sometimes moral truths about universal human rights. Without commenting on the separation of church and state, these individuals suggest the state is not morally neutral, and instead describe the state as having a moral obligation to uphold the rights of citizenship (see also Puri, 2016). This frame aligns with existing research suggesting that the Religious Right's use of religion to oppose LGBTQ rights has transformed LGBTQ activism to respond to this opposition (Fetner, 2008; Stone, 2016). We find that both sides turn to religious or moral grounds when making sense of proposed changes in the law that have to do with gender and sexuality (see also Mucciaroni, 2009).

The code we called "Universal truth" is prominent for those who favor nondiscrimination protection, and a parallel code, "God," was common for those in opposition. The former represented moral claims that evoked a sense of universal good or ethics but were not explicitly connected to any specific religion or doctrine. We used the "God" code for explicit references to religious beliefs or values, such as reference to God, Jesus Christ, or scripture.

Corroborating prior research (see Mucciaroni, 2009), we find elected officials who oppose gay rights are less likely to use morality claims than motivated and ordinary citizens, perhaps because of the expectation that elected officials respect the separation of church and state. Alternatively, many ordinary citizens who oppose nondiscrimination legislation shared explicitly religious beliefs, such as "it goes against God's will," "it is a sin," or "I'm a Christian. Scripturally, their lifestyle is wrong. Gov't should not endorse it." As these sentiments illustrate, Christianity and the Bible are the only religions and religious texts explicitly mentioned by ordinary citizens. One motivated citizen testifying in opposition to the proposed legislation noted: "God...prohibits men from wearing women's clothes and women from wearing men's clothes. He also declares homosexuality to be an abomination." Their rhetoric suggests Christian doctrine clearly opposes gay, lesbian, and transgender identities as immoral and against God's intentions. 
A small number of ordinary citizens make explicit reference to God or Jesus in justifying their support for employment nondiscrimination laws to include sexual orientation and gender identity, making comments such as "Jesus says to love all people" or "They are God's children like you and me.” More commonly ordinary citizens supported nondiscrimination laws by making appeals to morality (but not religion) and a shared humanity that is not diminished by sexual orientation or gender identity. For instance, people commented on the survey with sentiments like "I believe in human dignity for all," "people are people," "love is love," "we are all human," and "it's the right thing to do." These comments underscore a sense from ordinary citizens that they turn to questions about morality when thinking about legal issues and to justify their support for LGBT rights.

In contrast to what emerges from ordinary citizens, the elected officials who support employment nondiscrimination laws are more likely to explicitly reference God and religion in justifying their support. For instance, one senator shared an excerpt from a statement from the Heartland Clergy for Inclusion:

As Christian clergy, we proclaim the good news concerning lesbian, gay, bisexual, and transgender persons and publicly apologize where we have been silent... Silence by many has allowed political and religious rhetoric to monopolize public perception, creating the impression that there is only one Christian perspective on this issue. Yet we recognize and celebrate we are far from alone, as Christians, in affirming LGBT persons as distinctive, holy, and precious gifts.

Another senator expressed: "what's the greatest commandment? To love our neighbors as ourselves, to love God with all of our heart, soul, and mind." These comments speak to how some actors strive to speak from a Christian perspective to justify their support. Perhaps proLGBT elected officials-unencumbered by the stereotypes surrounding homophobic religious conservatives-think incorporating religious language will hold weight in a red state like Nebraska that is assumed to be religiously conservative. It reflects the desire, as the statement from Heartland Clergy makes explicit, to counter the claim that does 
emerge in ordinary and motivated citizens' framing that LGBTQ identities and Christian religious beliefs are antithetical.

For both sides and across different types of social actors, questions about employment nondiscrimination prompt reflection on bigger questions regarding the obligation of the state to uphold broader moral truths. This "big picture" perspective extends how individuals define citizenship as transcending any sexual orientation or gender identity.

\section{The Fair State: that Sexuality and Gender Should be Irrelevant}

Both sides support the notion that sexual orientation and gender identity are characteristics that should not have any bearing on their employability or activities as an employee, claims we coded as "Irrelevant." For instance, comments made by ordinary citizens in support-"how, or who they love has nothing to do with work, work ethic" and "sexual orientation has no impact on job performance"-echoed comments made by ordinary citizens in opposition-"not sure why that would ever be brought up. People should get jobs because they can do them better" and "sexual orientation should not be a factor considered in a job application." Sexuality and gender identity, in other words, are irrelevant to this form of citizenship because, at least in the case of employment nondiscrimination, these characteristics are not ones that should be relevant to workplace practices.

Likewise, elected officials across positions shared similar sentiments: "The only factors that should be used to determine whether someone qualifies for a job are their education and experience in the field and their ability to complete the tasks assigned to them" (senator who opposes) and "No one should be fired for who they are or who they love but, rather, the quality of their work" (senator who favors). Similar frames appeared in the discourse from motivated citizens testifying in favor of the legislation. However, this frame was less common for motivated citizens representing only $5 \%$ for those in favor and none for those opposing. One citizen testifying in support of the bill stated, "the point is that this is a straightforward bill. It's equal employment on the basis of merit. You could be fired on the basis of doing a bad job but not because you are gay, not because you are black, not because you are Catholic.” 
Ordinary citizens, motivated citizens, and elected officials on both sides claim that all people should be treated equally and fairly and use this to maintain that gender and sexuality are irrelevant. This supports existing research that finds that both conservatives and liberals my draw from "rights" rhetoric to support their claims (Lewis, 2017). For instance, ordinary citizens who oppose LGBT employment nondiscrimination laws justify their position stating "there should never be any time of discrimination" and "we are all equal!" Ordinary citizens who favor LGBT employment nondiscrimination laws agree: "All people should be treated equally!" One motivated citizen speaking in support of the bill invoked equality stating, "[we] place great importance on the equal treatment and fairness of all of our members of our community," while another citizen testifying in opposition argued that passing the bill would in effect discriminate against people with differing views arguing “The state of Nebraska's motto is 'Equality Before the Law.' Let's live up to that motto and allow those who maintain alternative views of sexuality the equality that we cherish. Let's include those who live by a traditional view of sexuality, one embraced by all cultures and countries for the last 2000 years." One elected official speaking in support of the bill stated, "you should not discriminate against [LGBT people] in our work force if you are a business in Nebraska.” Another elected official arguing against the bill invoked equality saying "Everyone, every single person should be treated with dignity and respect."

\section{The Diverse State: the Tension of Sexuality and Religion}

Despite using similar frames of morality and fairness across both sides of the debate, social actors differ with regard to how concerns of equality and fairness are applied within a diverse nation like the USA. Social actors who favor adding sexual orientation and gender identity as protected classes highlight that discrimination against LGBT people does occur and therefore requires distinct protection. In particular, motivated citizens and elected officials, as opposed to ordinary citizens, were likely to directly acknowledge existing discrimination. Motivated citizens and elected officials were also more likely to make statements we coded as "Personal" where they spoke directly about themselves or a person they knew who is LGBT and affected by the 
proposed law. For instance, elected officials speaking in favor of the legislation voiced the following perspectives to justify their position: "Can you imagine for a second going to work and being worried about even placing picture frames of your family in fear that that may cause you to be fired from your job?”

Some motivated citizens testifying in support of the bill spoke on behalf of their own experiences being LGBT in the workplace. As one motivated citizen put it: "So often LGBTQ individuals like myself are forced to hide, forced to lie, and forced to carefully navigate our daily interactions in order to protect ourselves and our employment." Other offered specific examples. A transgender citizen testifying stated,

"Since coming out over two years ago and transitioning on the job, I've been subjected to numerous gender-biased comments and discrimination" and a third citizen self-identified as queer and explained that after coming out at work "a supervisor, the woman who interviewed me, pulled me aside. We went to an empty room and sat down [...] She told me the community wouldn't be comfortable with it, that some of the other staff had already come to her, and that she was worried what parents and donors would think. She asked me to hide, to hide this part of myself.

These examples reflect personal accounts of when sexual orientation and gender identity were improperly and negatively made relevant to their workplace experiences.

In contrast, the frames used by social actors who oppose adding sexual orientation and gender identity as protected classes reflect the belief that discrimination against LGBT people does not occur. For instance, one elected official remarked:

I go to a lot of business seminars. I meet on a regular basis with a lot of business people who employ a lot of people and I've been in and out of their businesses and I see people, the full spectrum. And they hire people because of their qualifications. I've never heard a businessman say it's my practice not to hire a gay person. Don't see it...I just don't see the reason or the rationale to create a law which will one more time micromanage... 
This comment illustrates the logic that the proposed law is not necessary since employment discrimination against LGBT people does not occur. Others echoed the sentiment that a law was "unnecessary," according to one ordinary citizen. A motivated citizen who testified explained that he opposed the bill because: "I think...individuals have equal rights and I'm concerned that this class of individuals gets elevated, gets superior rights." These comments reflect the interpretation that creating a law would mean elevating gay, lesbian, and transgender individuals to a special and undeserved class and thus not treating all people equally.

Further, social actors' frames in opposition reflect a concern that adding sexual orientation and gender identity as protected classes might result in discrimination on the basis of religion. This frame emerged most in discourses of motivated citizens and elected officials who talk specifically from the perspective of respecting the freedom of religion and the ability for employers to practice their religious beliefs (see also Lewis, 2017; Kazyak et al., 2018). Their claims to God and the First Amendment underscore their logic that employer's freedom of religion would be restricted if employment nondiscrimination laws included sexual orientation and gender identity. For instance, a motivated citizen, the executive director at Nebraska Family Alliance, remarked:

We also believe that human sexuality is properly expressed in the union between one man and one woman in marriage... Religious institutions, family businesses, and private individuals should not be compelled to condone or participate in activities which violate their religious mission, or their sincerely held religious beliefs. We believe that LB173 represents the potential to compromise the right of Nebraskans to religious liberty.

A similar argument was made by a motivated citizen: "I ask you today to reject this bill so that no Nebraskan is dragged before courts and state commissions or punished by the government for peacefully seeking to live and work consistent with their belief about marriage." These motivated citizens shift the focus of discrimination away from LGBT people to religious persons holding anti-LGBT beliefs. 
The validity of LGBT identities, particularly transgender identity, was salient only in remarks by elected officials and motivated citizens who oppose LGBT nondiscrimination laws. One senator used the following scenario to argue against passage of the bill: "say, an individual who is male by perceived to the public, comes in, and comes in, in a dress, a skirt, and presents that way to the customers, and the customers show some level of discomfort at that, can the manager talk to that person, one, two, three times, and then be able to, upon the third time, upon the third transgression, terminate their employment?" This sentiment was echoed by a motivated citizen who expressed concern about the implication of the bill in protecting too expansive understanding of gender: "there is no immutable characteristic that you can assign to one's gender identity. There is no medical history that that person needs to produce as evidence. There is no consistency in that person's appearance to determine whether they're one gender identity or another." In other words, by protecting gender identity, the state advocates that gender is not an immutable characteristic assigned at birth. Another motivated citizen agreed and used the comparison to race to justify his opposition creating a law that would protect gender identity and sexual orientation because those characteristics as based in behavior, choice, and feelings as opposed to biology: "I'm saying that there is a fundamental difference between the behavior associated with sexual orientation or the choice that an individual [makes] to identify as one gender identity or another. There is a fundamental difference between that and being born black."

In sum, all social actors point to the importance that diverse citizens deserve the same, fair treatment in the workplace, but they come to opposite conclusions about protecting LGBT people compared to conservative religious values.

\section{Discussion}

The discourse surrounding the rights of LGBT people reveal deeply ingrained and broad assumptions about citizenship in civil society. Many of these are overlapping across different sides of the debate, yet they are unevenly and selectively applied depending on one's support or opposition to LGBT nondiscrimination legislation. We corroborate 
this observation when it comes to employment nondiscrimination, as other researchers have done on topics related to religious exemption laws, so-called bathroom bills, and marriage rights (Blumell et al., 2019; Callahan \& Zukowski, 2019; Hull, 2001; Kazyak et al., 2018; Mucciaroni, 2009; Stange \& Kazyak, 2016; Westbrook \& Schilt, 2014). Our unique contribution to this literature is to emphasize the frames used by various social actors, including ordinary citizens, motivated citizens giving public testimony during legislative debate, and elected officials, to show the ways in which sexuality and citizenship are discursively constructed from various perspectives.

This case study on the debate of one LGBT nondiscrimination policy shows how, in the words of Puri (2016), "governing sexuality helps account for the idea and inevitability of states" (p. 6). The counterfactual in arguments on both sides reveals inherent beliefs about citizenship rights conferred on straight, cisgender people. That is, the idea that a straight, cisgender person could be fired based on sexual orientation or gender identity is never considered; it is simply assumed as unjust. As social actors debate employment nondiscrimination, they are thus reckoning with the recognition and inclusion of LGBT people in the nation state. Even though both sides emphasize that sexuality and gender should be irrelevant in the workplace, their logics reveal different understandings about what that actually means.

Social actors who favor nondiscrimination protection for LGBT people constitute a world in which a person's sexual orientation and gender identity could be explicitly marked and made visible in the workplace (e.g., displaying photos a same-sex partner, having queer identity known among staff and customers, transitioning in the workplace) without it having an impact on how they are treated (e.g., not being fired as a result). The personal accounts from motivated citizens who testified in support of the proposed bill further bolster this position as their stories showcase instances where sexual orientation and gender identity were marked, but had a negative impact of their treatment in the workplace. From their viewpoint, by enacting a nondiscrimination law, the state would be a "fair state" and demark inclusion for LGBT identities in the workplace by allowing those identities to be visible but irrelevant to employment decisions (e.g. hiring and firing). 
In contrast, those who oppose nondiscrimination protection for LGBT people constitute a world in which a person's sexual orientation and gender identity should not be explicitly marked or made visible in the workplace. From their viewpoint, this world already exists (i.e., as the remark from one elected official illustrates "I've never heard a businessman say it's my practice not to hire a gay person”). Adding a nondiscrimination law would alter this world and the state would no longer be a fair state, but one that places sexual orientation and gender identity in an arena where it should have no bearing. Some opponents may go even further to suggest that when sexual orientation and gender identity is visible in the workplace, discriminatory action may be appropriate (i.e., the remark from an elected official suggesting an employer should be able to lawfully terminate a transgender employer if that employer's gender presentation makes customers uncomfortable). The degree to which people's opposition to nondiscrimination is out of animus towards LGBT identities and people, as some of the remarks particularly questioning the nature of transgender identity suggest, warrants attention in future work (Powell et al., 2015).

Religion and morality emerge as central frames as both sides and various types of social actors articulate that the state is not neutral but is expected to be an enforcer of values. Nevertheless, the sides differ on whose moral values the state ought to be enforcing and to what effect. In one sense, our findings corroborate prior work that shows how religious conservatives influence debates about LGBT rights (Fetner, 2008; Mucciaroni, 2009). Those who oppose nondiscrimination protections for LGBT people do so in part out of a religious conviction that views LGBT identities as immoral and against Christian teachings. Likewise, that elected officials speaking in support of nondiscrimination protections for LGBT people also explicitly reference Christian values speaks to the degree to which the elected officials are attempting to refute conservative Christian discourses that have been so prominent in anti- LGBT activism (D'Emilio, 2012; Fetner, 2008). Such findings mirror research that shows opposition to LGBT rights is correlated with conservative Protestant religious identification (Cox et al., 2014).

However, our findings also suggest that the terrain is perhaps shifting in how morality enters public debates about citizenship, sexuality, and gender. It was quite common for ordinary citizens to draw on 
morality frames, but not explicitly Christian ones, to justify their support of LGBT rights. This points to contestations about religion and moral values as they relate to sexuality and gender identity. Here the state is imagined as needing to protect universal values that transcend any one particular religion, values which are assumed to be threatened in the absence of employment nondiscrimination protections. Yet, the frame of religious discrimination and the need for the state to protect people's First Amendment rights that is salient in both citizens' and elected officials' testimonies highlights a new emerging rhetoric in relation to LGBT rights (Kazyak et al., 2018). The state is imagined as needing to protect Christian values, values which are assumed to be threatened in light of proposed employment nondiscrimination protections (Pew Research Center, 2019).

\section{Conclusion}

Research has shown that elected representatives respond to the concerns of constituents underscoring that the frames citizens use in their testimonies during legislative debates, for instance, can have a direct impact on legislative decisions (see McCammon et al., 2007, 2008). This article responds to calls from social movement researchers for greater attention to how various actors frame issues process (Soule \& King, 2006). The question of why such contestation occurs when there actually appears to be majority support for LGBT nondiscrimination warrants attention in future research (see Flores et al., 2015). Our work suggests that because frames surrounding LGBT nondiscrimination laws evoke broader ideas related to the nature of sexuality, gender, and citizenship, these laws will continue to be contested by ordinary citizens, social movements, and elected officials.

The rights and belonging of citizenship are of fundamental concern to all civil societies. While these rights are often assumed to be conferred on all people designated as citizens in a society, the current project reveals that the question of LGBT people's inclusion in the state remains contested (Canaday, 2009; Richardson, 2018). Further still, religious arguments used to prevent LGBT nondiscrimination rights remain salient in post-gay marriage American society. At the same time that the Bostock decision extended workplace discrimination 
protections to LGBT people, conservative stalwart Justice Neil Gorsuch wrote a sober warning in his majority opinion. In his reading, the religious beliefs of an employer may "supersede" the Title VII protections now being extended to the LGBTQ community. Gorsuch notably referred to the Religious Freedom Restoration Act, passed by Congress in 1993 to protect an individual's practice of their faith, as a "super statute" and emphasizes the court's mandate to uphold "the promise of the free exercise of religion enshrined in our Constitution." It is an issue that courts will likely have to decide on a case-by-case basis in the future. Continued analysis and explication of these debates are essential to establishing a deeper understanding of the social context for legal policy relating to LGBT individuals.

Acknowledgments This research was partially supported by the University of Nebraska Lincoln Department of Sociology Haas Faculty Summer Grant and USTAR program. We thank Micah Levine, Jordan Malzer, and Claire Bartels for their research assistance.

\section{References}

Adam, B. D. (2003). The Defense of Marriage Act and American exceptionalism: The "gay marriage" panic in the United States. Journal of the History of Sexuality, 12(2), 259-276.

Barclay, S., Bernstein, M., \& Marshall, A. M. (Eds.). (2009). Queer mobilizations: $L G B T$ activists confront the law. NYU Press.

Baumle, A. K., Badgett, M. V., \& Boutcher, S. (2019). New research on sexual orientation and gender identity discrimination: Effect of state policy on charges filed at the EEOC. Journal of Homosexuality, 67(8), 1135-1144.

Benford, R. D., \& Snow, D. A. (2000). Framing processes and social movements: An overview and assessment. Annual Review of Sociology, 26, 611-639.

Bernstein, M., \& Reimann, R. (Eds.). (2001). Queer families, queer politics: Challenging culture and the state. Columbia University Press.

Berrey, E., Nelson, R. L., \& Nielsen, L. B. (2017). Rights on trial: How workplace discrimination law perpetuates inequality. University of Chicago Press.

Blair-Loy, M. (2001). Cultural constructions of family schemas: The case of women finance executives. Gender \& Society, 15(5), 687-709.

Blumell, L. E., Huemmer, J., \& Sternadori, M. (2019). Protecting the ladies: Benevolent sexism, heteronormativity, and partisanship in online discussions of gender-neutral bathrooms. Mass Communication and Society, 22, 365-388. 
Bonikowski, B., \& DiMaggio, P. (2016). Varieties of American popular nationalism. American Sociological Review, 81, 949-980.

Brown, H. E. (2013). Race, legality, and the social policy consequences of antiimmigration mobilization. American Sociological Review, 78(2), 290-314.

Burke, M. C., \& Bernstein, M. (2014). How the right usurped the queer agenda: Frame co-optation in political discourse. Sociological Forum, 29(4), 830-850.

Callahan, M. P., \& Zukowski, K. T. (2019). Reactions to transgender women and men in public restrooms: Correlates and gender differences. Journal of Homosexuality, 66(1), 117-138.

Canaday, M. (2009). The straight state: Sexuality and citizenship in Twentieth Century America. Princeton University Press.

Carrillo, H. (2017). Pathways of desire: The sexual migration of Mexican gay men. University of Chicago Press.

Cress, D. M., \& Snow, D. A. (2000). The outcomes of homeless mobilization: The influence of organization, disruption, political mediation, and framing. American Journal of Sociology, 105(4), 1063-1104.

Corbin, J., \& Strauss, A. (1990). Grounded theory research: Procedures, canons, and evaluative criteria. Zeitschrift für Soziologie, 19(6), 418-427.

Crabtree, B. F., \& Miller, W. L. (1992). A template approach to text analysis: Developing and using codebooks. In B. F. Crabtree \& W. L. Miller (Eds.), Research methods for primary care, Vol. 3. Doing qualitative research (pp. 93109). Sage Publications, Inc.

Cox, D., Navarro-Rivera, J., \& Jones, R. P. (2014). A shifting landscape: A decade of change in American attitudes about same-sex marriage and LGBT issues. Public Religion Research Institute.

D'Emilio, J. (2012). Sexual politics, sexual communities. University of Chicago Press.

Dejka, J. (2013). Schools' insurer to offer benefits for spouses of gay employees. Omaha World Herald.

Feinberg, M., \& Willer, R. (2015). From gulf to bridge: When do moral arguments facilitate political influence? Personality and Social Psychology Bulletin, 41(12), 1665-1681.

Ferree, M. M., Gamson, W. A., Rucht, D., \& Gerhards, J. (2002). Shaping abortion discourse: Democracy and the public sphere in Germany and the United States. Cambridge University Press.

Fetner, T. (2008). How the religious right shaped lesbian and gay activism. University of Minnesota Press.

Flores, A. R., Herman, J. L., \& Mallory, C. (2015). Transgender inclusion in state non-discrimination policies: The democratic deficit and political powerlessness. Research \& Politics, 2(4), 1-8.

Funk, J. (2013). Most Nebraska schools to offer same-sex benefits. Associated Press. 
Ghaziani, A., \& Baldassarri, D. (2011). Cultural anchors and the organization of differences: A multi-method analysis of LGBT marches on Washington. American Sociological Review, 76(2), 179-206.

Glissmann, B. (2013). Starting in 2014, some Nebraska hospitals will cover samesex couples. Omaha World Herald.

Goldberg-Hiller, J., \& Milner, N. (2003). Rights as excess: Understanding the politics of special rights. Law \& Social Inquiry, 28(4), 1075-1118.

Gruszczynski, M., \& Michaels, S. (2014). Localized concerns, scientific argumentation, framing, and federalism: The case of Devils Lake water diversion. Journal of Natural Resources Policy Research, 6(2-3), 173-193.

Hamilton, M. A. (2015). The case for evidence-based free exercise accommodation: Why the Religious Freedom Restoration Act is bad public policy. Harvard Law \& Policy Review, 9, 129.

Herman, D. (1997). The antigay agenda: Orthodox vision and the Christian Right. University of Chicago Press.

Hull, K. E. (2001). The political limits of the rights frame: The case of same-sex marriage in Hawaii. Sociological Perspectives, 44(2), 207-232.

Kazyak, E., Burke, K., \& Stange, M. (2018). Logics of freedom: Debating religious freedom laws and gay and lesbian rights. Socius, 4, 1-18.

Lewis, A. R. (2017). The rights turn in conservative Christian politics: How abortion transformed the culture wars. Cambridge University Press.

McCammon, H. J., Muse, C. S., Newman, H. D., \& Terrell, T. M. (2007). Movement framing and discursive opportunity structures: The political successes of the US women's jury movements. American Sociological Review, 72(5), 725-749.

McCammon, H. J., Chaudhuri, S., Hewitt, L., Muse, C. S., Newman, H. D., Smith, C. L., \& Terrell, T. M. (2008). Becoming full citizens: The US women's jury rights campaigns, the pace of reform, and strategic adaptation. American Journal of Sociology, 113(4), 1104-1147.

Minow, M. (1987). Interpreting rights: An essay for Robert Cover. The Yale Law Journal, 96, 1860-1915.

Movement Advancement Project. (2020). Equality maps: State nondiscrimination laws. Retrieved from https://www.lgbtmap.org/equality-maps/ non discrimination laws

Mucciaroni, G. (2009). Same sex, different politics: Success and failure in the struggles over gay rights. University of Chicago Press.

Oliver, P. E., \& Johnston, H. (2005). What a good idea! Ideologies and frames in social movement research. In Frames of protest: social movements and the framing perspective (pp. 185-204). Rowman \& Littlefield Publishers, Inc.

Olsen, K. A. (2014). Telling our stories: Narrative and framing in the movement for same-sex marriage. Social Movement Studies, 13(2), 248-266.

Pakulski, J. (1997). Cultural citizenship. Citizenship Studies, 1(1), 73-86.

Pedriana, N. (2006). From protective to equal treatment: Legal framing processes and transformation of the women's movement in the 196os. American Journal of Sociology, 111(6), 1718-1761. 
Pew Research Center. (2014). Religious landscape study. http://www.pewforum. org/religious-landscape-study/geography

Pew Research Center. (2019). Sharp rise in the share of Americans saying Jews face discrimination. https://www.pewresearch.org/politics/2019/04/15/ sharp-rise-in-the-share-of-americans-saying-jews-face-discrimination/

Powell, B., Quadlin, N. Y., \& Pizmony-Levy, O. (2015). Public opinion, the courts, and same-sex marriage: Four lessons learned. Social Currents, 2(1), 3-12.

Puri, J. (2016). Sexual states: Governance and the struggle over the antisodomy law in India. Duke University Press.

Rasmussen, C. E. (2006). We're no metro sexuals: Identity, place and sexuality in the struggle over gay marriage. Social \& Cultural Geography, 7(5), 807-825.

Reed, L. (2012). Domestic partners to get benefits at NU. Omaha World Herald.

Reich, G., \& Mendoza, A. A. (2008). "Educating kids" versus "coddling criminals": Framing the debate over in-state tuition for undocumented students in Kansas. State Politics \& Policy Quarterly, 8(2), 177-197.

Richardson, D. (2018). Sexuality and citizenship. Sexualities, 21(8), 1256-126o.

Riggle, E. D. B., Rostosky, S. S., \& Horne, S. G. (2010). Psychological distress, wellbeing, and legal recognition in same-sex couple relationships. Journal of Family Psychology, 24(1), 82-86.

Snow, D., Benford, R., McCammon, H., Hewitt, L., \& Fitzgerald, S. (2014). The emergence, development, and future of the framing perspective: $25+$ years since "frame alignment." Mobilization: An International Quarterly 19(1), 23-46.

Soule, S. A., \& King, B. G. (2006). The stages of the policy process and the Equal Rights Amendment, 1972-1982. American Journal of Sociology, 111(6), 1871-1909.

Stange, M., \& Kazyak, E. (2016). Examining the nuance in public opinion of proLGB policies in a "red state." Sexuality Research \& Social Policy, 13, 142-157.

Stein, A. (2001). The stranger next door: The story of a small community's battle over sex, faith, and civil rights. Beacon Press.

Stone, A. L. (2016). The impact of anti-gay politics on the LGBTQ movement. Sociology Compass, 10(6), 459-467.

Stone, A. L. (2019). Frame variation in child protectionist claims: Constructions of gay men and transgender women as strangers. Social Forces, 97(3), 1155-1176.

The American Association for Public Opinion Research. (2016). Standard definitions: Final dispositions of case codes and outcome rates for surveys (9th ed.). AAPOR.

Turley, J. (2008). An unholy union: Same-sex marriage and the use of governmental programs to penalize religious groups with unpopular practices. Same-sex marriage: Emerging conflicts.

Turner, B. S. (Ed.). (1993). Citizenship and social theory. Sage Publications, Inc. Valocchi, S. (1999). Riding the crest of a protest wave? Collective action frames in the gay liberation movement, 1969-1973. Mobilization: An International Quarterly, 4(1), 59-73. 
Van Dyke, N., \& Taylor, V. (2019). The cultural outcomes of social movements. In D. A. Snow, S. A. Soule, H. Kriesi, \& H. J. McCammon (Eds.), The Wiley Blackwell companion to social movements (pp. 482-498). Wiley.

Vasi, I. B., Walker, E. T., Johnson, J. S., \& Tan, H. F. (2015). “No fracking way!” Documentary film, discursive opportunity, and local opposition against hydraulic fracturing in the United States, 2010 to 2013. American Sociological Review, 80(5), 934-959.

Vitulli, E. (2010). A defining moment in civil rights history? The employment non-discrimination act, trans-inclusion, and homonormativity. Sexuality Research and Social Policy, 7(3), 155-167.

Walters, S. D. (2016). The tolerance trap: How God, genes, \& good intentions are sabotaging gay equality. New York University Press.

Westbrook, L., \& Schilt, K. (2014). Doing gender, determining gender: Transgender people, gender panics, and the maintenance of the sex/gender/ sexuality system. Gender \& Society, 28(1), 32-57.

Worthen, M. G. F. (2019). A rainbow wave? LGBTQ liberal political perspectives during Trump's presidency: An exploration of sexual, gender, and queer identity gaps. Sexuality Research and Social Policy, 17, 263-284.

Ygnvesson, B. (1993). Virtuous citizens, disruptive subjects: Order and complaint in a New England Court. Routledge. 